\title{
16 Christian charity as the last line of defense for migrants in Ventimiglia
}

\author{
Juan Pablo Aris Escarcena
}

\section{Introduction}

The migration 'crisis' in Europe has led to the reappearance of border controls within the European internal space established by the Schengen agreements and the European Union's (EU) Area of Freedom, Security and Justice. In several countries - France, Austria, or Switzerland border controls have been recently re-established. This decision was justified by invoking security reasons, including terrorism, and excessive migration presented as a threat to the stability and social order of European countries.

Expulsion strategies have been developed in several of the border areas. Hostile environments have been built using different techniques: prohibiting tents to prevent refugees from sleeping outdoors, banning food distributions, and prosecuting volunteers assisting migrants. In the extreme cases, such as that of Cedric Herrou, a French farmer who provided support to migrants in the border area between France and Italy, volunteers were convicted for 'crimes of solidarity' (Tazzioli \& Walters 2019).

In Ventimiglia - the closest Italian town to France on the coast - all of these techniques have been implemented. The border between Italy and France has become a hostile environment, a result of political measures of both states. However, the social influence of the Catholic Church has served as a last line of defense ${ }^{1}$ to curb the effects of the expulsion tactics.

This chapter analyzes how the governmental actions created a hostile environment in Ventimiglia, and how the cultural link with the Catholic value of charity ${ }^{2}$ has resulted in creating spaces of defense against persecution of migrants. It focuses on the forms of activism developed by 'Catholic organizations,' i.e. civil society voluntary organizations coordinated and led by local church or religious group. It does not refer to organizations based on the ecclesiastical hierarchy, but to those that arise from local interaction between citizens and the Catholic Church. The concept of charity is a multifaceted and complex concept. This chapter presents the practices that different organizations and actors have carried out motivated by charity. These experiences are the basis of the of the definition of charity given at the end 


\section{4}

J. P. Aris Escarcena

of the chapter. Likewise, the chapter reflects on the limits of the social definition of moral values, on their potentialities and risks.

This chapter is based on ethnographic fieldwork carried out in Ventimiglia between October and December 2017, as well as in June 2018. The research was carried out through participant observation of different civil society organizations. This ethnographic work is part of a larger research project ${ }^{3}$ based on multi-sited ethnography across different locations on the borders of the EU, such as Ceuta and Melilla (Spanish enclaves in North Africa), Calais (France), and Katsikas (Greece).

\section{The creation of a hostile environment: Ventimiglia}

The city of Ventimiglia is the closest Italian urban center to France on the Mediterranean Côte d'Azur. The city is located at the mouth of the valley of the Roya river, near to Menton, the first French city on the coast. The proximity to the border with France has always been a fundamental source of resources for the city, including border trade.

In 2011, this small city of 24,000 inhabitants became the main site for an enormous transformation in the EU policies for managing migratory flows. As Sabine Hess and Bernd Kasparek (2017) point out, the re-establishment of border controls within the Schengen Area by France on its border with Ventimiglia was the trigger for a political process that would eventually result in the modification of the Schengen Border Code (SBC) (European Union 2016). From 2013 onwards, a provision was included in the Schengen Border Code allowing the member States of the EU to re-establish border controls in the Schengen area. This provision was reinforced in 2016, with the inclusion of a chapter dedicated to the conditions and modalities for the re-establishment of controls at the internal borders of the Schengen area. It is noteworthy that the recent $\mathrm{SBC}$ amendment extended the period allowing member states to re-establish border controls for up to six months (in 30day renewable tranches) in ordinary circumstances, and up to two years in extraordinary circumstances (Chapter II, Art. 25). The question of how an extraordinary situation is defined is one of the most controversial points of the European normative provisions. An extraordinary situation is one that poses a serious and unforeseen threat to the social order of a member state, but it is the states themselves who evaluate the situations and declare unilaterally that a situation is extraordinary.

Due to the prolonged closure of the borders in Ventimiglia by the French government in 2011 (ASAFFRON Association 2017) and subsequently after the 2015 attacks in Paris, Ventimiglia became a key place on the migratory route to the countries of Central and Northern Europe. In this small city, migrants who were trying to reach France without the necessary administrative permits were waiting for an opportunity to enter the country.

In Italy, the political response to the re-establishment of border controls by France has been very controversial (for a broader understanding of the 
situation in Italy see Chapter 15 in this volume). The policies of local and state authorities have been in constant tension between the quest to control migration and offer a solution and the quest to avoid the presence of large groups of migrants in the territory of the border city. The result was the creation of a hostile environment, where the presence of migrants was not welcomed and attempts were made to encourage the disappearance of migrants from the area with ad hoc political measures. This has been done through three processes: 1) denial of housing spaces; 2) prohibition of food distributions; and 3) expulsion from the territory of the city.

These political stances were rejected by civil society, including Catholic organizations, which played a fundamental role in the coordination of humanitarian assistance and the defense of migrants' rights.

\section{The denial of housing spaces}

In 2015, just after the borders were newly closed by the French state, migrants who were prevented by the police from entering the French territory did not settle in Ventimiglia, but remained as close as possible to the border crossing. Thus, the breakwaters and a small pine forest in the town of Balzi Rossi became de facto a makeshift shelter for the migrants; the group of migrants became progressively large, averaging 100 and reaching approximately 200 people at its peak.

The camp in Balzi Rossi was set up under the San Ludovico bridge. Migrants piled old tents and other substandard housing to protect themselves from the cold and rain next to a tourist parking lot. The camp was run by the migrants themselves in collaboration with activists from the No Borders group, a network of local organizations defined by its 'struggle alongside with migrants and asylum seekers for freedom of movement, for the freedom for all to stay in the place, which they have chosen, against repression and the many controls which multiply the borders everywhere in all countries' (Noborder Network 2004; see also Alldred 2003; Burridge 2010). This camp was active until 30 September 2015, when the Italian police bulldozed the makeshift shelters and migrants' belongings: tents, sleeping bags, mattresses, and blankets. Afterwards the migrants left the border enclave and Ventimiglia became the place from which to undertake the increasingly risky border-crossing into France.

For a few months, the migrants in Ventimiglia were dispersed throughout the city, sleeping in parks, streets, and in the vicinity of the train station the arrival point for most migrants seeking to continue their journey to France - where the government decided to set up emergency facilities, including a set of military tents managed by the Italian Red Cross.

In May 2016, following the visit of the then Minister of Interior, Angelino Alfano, the emergency facilities were closed, and the Red Cross was forbidden to distribute food and hygiene kits in the vicinity of the station. The government declared it wanted to seek reception systems for migrants in the 
cities of Milan and San Remo, thus preventing the growth of the migrant population in Ventimiglia. However, the result was that hundreds of people were again sleeping outdoors albeit in different parts of the city.

\section{The opening of the Delle Gianchette Church}

On May 31, 2016, the parish priest of the Church of Sant'Antonio Delle Gianchette - Fr. Rito Álvarez - decided to offer the church as a shelter for migrants who had nowhere else to go. This decision was presented as a response to the call of Pope Francis that parishes and communities welcomed refugees (Faiola \& Birnbaum 2015).

In one month, about 1,000 migrants sought shelter in the church, which became a place of reference also for the volunteers willing to show solidary with migrants and assist them. The volunteer mobilization was enormous, first through groups of parishioners of the Delle Gianchette Church and neighborhood residents and later from other parts of Italy and France. Many of the parishioners were descendants of Calabrian migrants or were migrants themselves (on the importance of migration memory see Chapter 2 in this volume). Despite the outpouring of solidarity and volunteer assistance, the prefecture forced the Church to close its doors and expel the migrants residing there.

It should be noted that the opening of the Delle Gianchette Church greatly impacted volunteer activism. Many volunteers became involved in providing assistance to the migrants. Antonio, a retired cook who frequently collaborated with the church and with Caritas said: 'I came to cook here from time to time, and one day we had to cook for 300 people. Now I come every day to cook for the migrants and for all those who need it.'

The support of the parish for the migrant community was a positive reinforcement for the local population, who maintained an attitude of solidarity with the migrants in spite of the potential difficulties that the incorporation of 1,000 people in a working-class neighborhood of Ventimiglia could pose for their daily lives. The positive effect of the parish leadership on the local participation was confirmed when, more than a year later, the parish stopped welcoming migrants and many of the people who were mobilized to support the project abandoned their involvement with the migrant community.

It is noteworthy how the support of migrants by the local parish prevented the expulsion of individual volunteers and non-religious organizations assisting migrants in Ventimiglia. Even groups with distant positions from the Catholic Church, such as the No Borders organization, continued to work in the city, in stark contrast with the criminalization suffered in Balzi Rossi or in the Roya Valley (Giliberti 2018). The case of the renowned French activist, Cédric Herrou, who started his activism by moving vulnerable migrants from the Delle Gianchette Church to his farm in Breil-sur-Roya is an example of criminalization of assistance to migrants. Herrou was accused by the 
French government of smuggling migrants. However, in 2018, the Constitutional Court of France affirmed that his humanitarian aid on French territory was an expression of the constitutional principle of fraternity and could therefore not be considered a crime. However, assisting migrants to cross the border or to circulate within the territory of the country continues to be the subject of French judicial scrutiny. On the contrary, the people involved in the church reception project have never been sanctioned in any way. The administrative measure foglio di via, by which a citizen can be expelled from a municipality for reasons of public safety and prohibited from returning to that municipality for three years was often used instead against other associations, but never against those affiliated with the church.

\section{The reaction of public authorities}

Reception in the church proved to be a very effective advocacy strategy. In addition to the humanitarian assistance, the social and cultural capital that the local parish was able to mobilize in defense of this project forced the public administration to revise its migration management policies. The opening of the church to migrants quickly prompted the state authorities, namely the Prefecture of Imperia, and the local authorities to contact each other and begin negotiations. At first, the public authorities demanded that the church reception project be stopped on the grounds that the structure did not have the appropriate characteristics to carry out reception under dignified conditions. Arguably due to the strong social support for the project, the parish refused to comply with such request until a structure that could accommodate migrants was established. This forced the authorities to open a reception complex, the Parco Roya, a new camp composed of containers and military tents, about five kilometers away from the Delle Gianchette Church.

The Parco Roya was established in June 2016, and it was again managed by the Italian Red Cross. However, the Delle Gianchette Church continued to welcome families, women, and children, as the camp did not have adequate space for everybody. In February 2017, the camp was temporarily closed due to an accidental fire, and the few people who lived there were moved. Upon its reopening in March of the same year, the internal structure of the camp and its policies were changed: entrance was conditional upon a fingerprint screening that was checked against the Eurodac database (European Union 2013). The database is used to determine which European country is responsible for the asylum application of a particular migrant. According to the Dublin agreement, migrants must request asylum in the first country of arrival within the EU or be returned (European Union 2000).

Faced with these regulations, many migrants refused to be sheltered in Parco Roya. The required controls clashed with their plans to migrate to other European countries (and to present their asylum application there). As a migrant from South Sudan pointed out in an interview: 'We don't want to 
stay in Italy, we come from a British colony and we speak English since we're children.... Why do we have to stay in Italy? It's one of the things I don't understand about Europe.'

The consequence was the birth of an informal camp under the bridge of the SS20 motorway, in the same street (Via Tenda) where the Delle Gianchette Church is located. These campsites sprung up before, even when the church welcomed all migrants, but they were an exception and they included isolated tents located either on the banks of the river or under the railway bridge. The church was also involved in assisting migrants who were beginning to live outdoors. The police prevented any type of construction, therefore migrants improvised and spread blankets on the damp ground, people slept clinging together for warmth, bonfires were kept lit next to their heads to fight the cold and scare rats, mountain-cold water was used for personal cleaning. Insecurity and the fear of being deported was part of everyday life under the bridge.

State and local authorities saw this situation as an obstacle to their efforts to control and move migrants to the outskirts of the city. Again, the church was required to stop providing assistance to migrants, and once again it argued that families, women, and children could not be left homeless. However, the authorities hastened the opening of dedicated structures for women and minors in Parco Roya, and on August 14, 2017, the Sant'Antonio Delle Gianchette Church closed its doors ending a 440-day long reception project. Since then, the church has repeatedly welcomed migrants, but only on ad hoc basis to prevent them from staying outdoors during storms; it has never again been used as a stable shelter. And in front of it, hundreds of migrants continued to live outdoors for an entire year until they were expelled in the spring of 2018. Some migrants went to Parco Roya, but many others slept in the streets and on the Roya River banks.

\section{The heritage of the Delle Gianchette Church}

In spite of the official end of the church's project, an informal network of volunteers emerged and sheltered vulnerable migrants in their own homes. These volunteers had met while participating in the church activities and were aware of the limitations of the official reception system and the dangers migrants faced both in the Parco Roya and in the informal camps. This newly emerged network sought alternative housing for the most vulnerable, mainly mothers with their children, and young women at risk of falling into the hands of traffickers and prostitution networks. Manuela, a volunteer in this network, explained to me that:

They had formed a wonderful group of people who took responsibility for protecting people. Whatever happens (referring to the legal problems that volunteers could face if the police found them sheltering 
families or, above all, unaccompanied minors) we cannot allow innocent people to sleep there, under a bridge or camp without any protection.

This historical analysis helps to show the strength and potential of the projects led by Catholic organizations in Ventimiglia and beyond. During the fieldwork carried out in Palermo in 2018, I had the opportunity to observe the fundamental difference the support of Christian organizations - such as the Network Against Racism in Palermo - has made in defending migrants' rights. The leadership taken by the local parish meant that the volunteers did not have to fear any legal reprisals. The involvement of the church also increased the negotiating capacity of the project with authorities. Ventimiglia's experience shows how Catholic organizations can activate citizen responses by appealing to shared cultural conceptions of ethics and fairness, which other organizations are unable to trigger. However, the capacity to generate community engagement and social mobilization through the demand for shared humanitarian values is also one of the limitations of Catholic activism. In Ventimiglia, the Delle Gianchette Church reception project was not based on a political critique of migration governance or of the official migration reception policies, but on the immorality of leaving hundreds of people without shelter. When an alternative was offered by the authorities, the project was not able to overcome this limit because it would have implied a political criticism of the legislation regulating the management of migratory flows. Thus, the legitimacy and social mobilization capacity of Catholic activism in Ventimiglia proved unbeatable when it came to leading a humanitarian project, but was limited with respect to the possibility of defending a political claim. This can be seen even more clearly in the events concerning the issue of the prohibition of food distributions to migrants.

\section{The prohibition of food distribution}

The closing of the official camp at the train station in 2016 was accompanied shortly afterwards by a ban imposed by local authorities on the distribution of food to migrants. In August 2016, this ban became unwavering; Mayor Enrico Ioculano issued Ordinance no. 126/2016 aiming to enforce a 'prohibition of distributing and/or supplying food and beverages in public areas by unauthorized persons.' The ban is not an exceptional practice; it is a widespread strategy developed in different contexts by various local and national governments in the EU during the so-called 'migration crisis' in an effort to create environments hostile to migrants (for a comparative analysis of these practices in Calais and Ventimiglia, see Aris Escarcena \& Da Silva 2018).

This ordinance exempted Catholic activism. Thus, the ordinance collected and legitimized the distributions made in the official reception center and in the headquarters of Catholic activism: the church Delle Gianchette Church and the facilities of Caritas Ventimiglia-San Remo. Indeed, the existence of 
Catholic activism was used by local authorities to justify prohibiting other groups to distribute food.

Nevertheless, the ban affected the volunteers of Catholic solidarity projects: the distribution of food was paradoxically strictly forbidden in the square facing the entrance of the Delle Gianchette Church. This was not a coincidence, but a direct effect of the logic of local politicians, whose aim was twofold: 1) to limit and contain the solidarity movements inside the church; and 2) to oblige the migrants to move to Parco Roya, away from the camping area under the bridge.

The limitations imposed on Catholic volunteers by the food distribution ban significantly advanced these two objectives. According to its own statistics, during 2017 Caritas Ventimiglia-San Remo offered food assistance to an average of more than 2,000 migrants per month, with the peak in August with just over 2,900 people. This assistance mobilized daily more than a dozen volunteers from Monday to Saturday throughout the year. The ban on distributing food was intended to prevent other groups, including those volunteering with Caritas or with the church, from distributing food at night. Thus, besides the breakfast offered by Caritas, many migrants could not receive any food assistance for the rest of the day, which left them with the difficult choice of either going to the official camp or, if they had financial means, look for some place to dine in the city. Both options were inconvenient for those who wanted to continue their journey to France: accessing the camp required inclusion in the Eurodac database; moving towards the city meant leaving the 'tolerance zone' around the church outside which the police forces regularly detained undocumented migrants to deport them to Taranto (in the far South of Italy). The intention was therefore to force migrants who wished to remain in the territory to head for the newly established camp.

\section{The creation of a division within the active civil society in Ventimiglia}

It is important to underscore the social support for local Catholic organizations and the inability of local authorities to prevent their functioning. This social capital is manifested in the fact that local authorities, instead of opposing food assistance by Catholic organizations, tried to restrict volunteer projects that were born alongside them. As pointed out earlier, it is worth analyzing the governmental actions in relation to the interconnection that occurred between volunteers who joined the activities of Catholic organizations first, but whose solidary often exceeded the original projects. The local government, not being able to discredit the Catholic organizations, decided to create a binary opposition between the actions of Catholic activists and the actions carried out by other organizations such as No Borders, Kesha Niya or $20 \mathrm{~K}$. In this way, the local population, which mainly volunteered with Catholic organizations, did not become involved in the actions carried out by other - foreign - organizations. The aim was to prevent 
entities coming from other parts of Italy or from European solidarity movements from putting down roots in local communities through the involvement of local volunteers. This was only partially achieved. While for the majority of the volunteers working in Catholic projects the threat of financial sanctions imposed by the local government for the participation in foreign organization's projects was a deterrent, there was a minority that nevertheless supported other initiatives and allowed these projects to remain in the territory.

On the other hand, Catholic organizations broke the imposed limitations on holidays and days of significant migrant arrivals, as well as on stormy days, when they offered hot drinks and food to migrants at the door of the Delle Gianchette Church or at the train station. During a food distribution on a rainy day one week before Christmas, the volunteers occupied a waiting room of the train station. There, a volunteer told me: 'It is a crime not to give something to eat or a shelter to people who arrive here at night. They arrive completely disoriented, with nothing, sometimes wet and hungry. Per caritá! ["For God's sake!" Literally translated as "for charity's sake"] ... you have to have a little humanity and put yourself in their place' (Volunteer 1, 2017). The local authorities never responded to these activities and the volunteers who carried them out were never compelled to comply with the food distribution ban.

\section{The paradoxical situation of local authorities with respect to humanitarian values}

The moral legitimacy of humanitarian assistance meant that local authorities had to adapt their arguments about migration control policies. The prohibition of food distributions was presented as a measure for the health of migrants: it was presented as an effort by local authorities to ensure that migrants did not receive spoiled food.

When reflecting on the embodiment of values in the migrant reception processes as well as in migration management policies, the prohibition of food distribution and its argumentation are significant. The claim of the local authority for the defense of the welfare of migrants implies falsifying of the fundamental cultural values of the local society, which Catholic organizations actively defended with their assistance. Catholic activism is based on selfless assistance to those in an emergency situation and is represented by the figure of the Good Samaritan. This value is strongly rooted in the culture of European societies and is the basis of legal constructions that have gone beyond their own national legal systems (Pardun 1997) and has established itself as a fundamental principle in international law (an example is the law of the sea, UNCLOS). Charity, as a foundational value of public law, is undermined by such interpretations from the authorities (local in this specific case). The action of Catholic organizations in these contexts becomes thus the last line of defense of both migrants and of a fundamental ethical 
principle, deeply rooted in European societies, as demonstrated by the great response of European citizens to the situation of helplessness and indigence suffered by migrants arrived during the historical phase of the so-called 'refugee crisis.'

\section{The instrumentalization of humanitarian assistance by the authorities}

In the construction of migration management policies, the authorities have used the fundamental values of charity and solidarity in a sense that betrays ethical foundations. The concern for the well-being of migrants expressed in Catholic activism is used to legitimize political projects that directly attack the basic interests of migrants. Thus, instead of showing the contradiction between certain political ends and fundamental humanitarian values, an attempt is made to present these as the basis for political measures such as the prohibition of food distribution. On the other hand, the authorities use the existence of projects led by Catholic activism to reject the need for other forms of volunteerism. The Catholic organizations in Ventimiglia did not formally oppose the ban as long as they were tolerated by the authorities. Unlike the demands made by Catholic organizations regarding the need for public housing structures for migrants in Ventimiglia, there was no claim regarding the need for a public service for food distribution. These inconsistencies lead to a reflection on the limits of Catholic activism and the transformations in the values and conceptions of social solidarity within the institutions linked to the Catholic Church in a political context marked by the opening of all areas of the welfare state to commercialization, as Gray (2016) points out in his analysis of the pro-migrant policies of the Irish Catholic Church.

Volunteering in Catholic organizations was the main way, in which local citizens put into action their moral convictions about the need to assist and to 'do good.' However, the mobilization of social values profoundly linked to the Christian ethic of charity must be analyzed in relation to the transformations of the Church's conceptions on how to organize the moral responsibilities in the current historical context.

\section{Expulsion from the territory}

The limits of the Catholic organizations' actions can be seen in their lack of response to the deportations that took place in Ventimiglia (and that continued to take place at the end of 2018). There were two types of deportation: 1) 'returns' from France to Italy, and 2) deportations (internal deportations) within the Italian territory from North to South.

Returns followed two schemes: deportation of asylum seekers under the Dublin System, and - more relevant for the present analysis - the direct returns under the bilateral Chambery Agreement (République Française \& Repubblica Italiana 2000), an agreement signed by Italy and France to 
manage migration and shared border areas. The Chambery Agreement created an 'express' procedure whereby migrants who were intercepted travelling from Italy to France without permits were immediately deported back to Italy. Different groups of activists, such as Roya Citoyenne or No Borders, opposed this type of semi-legal procedure, which in many cases oversteps legal boundaries as is the case of deportations of unaccompanied minors who should have been placed in the custody of the State (ASGI 2018).

Internal deportations are based on the need for the correct identification of migrants in the Eurodac database and on the 'decompression' of reception structures in Northern Italy. In practice, this meant that those who were apprehended when traveling to France without permits were detained, and subjected to a control to verify whether any documentation on their identity existed and whether their fingerprints had been correctly entered into the Eurodac database; if this was not the case, they were taken into police custody and sent to the hotspot of Taranto. This served as a deterrent and forced migrants to make long journeys or spend their money to return to Ventimiglia. This practice has been strongly denounced by various organizations in Italy (Quadroni \& Luppi 2016).

The situation described above was the third problem encountered by migrants during their presence in Ventimiglia. Beyond the pertinence and il/ legality of this type of dynamic in the management of migrations and borders, if the issue is approached from the point of view of migrants, these practices constitute a source of uncertainty and suffering. Apprehensions and deportations were carried out all over Ventimiglia: all migrants who approached the train station, the market, the health institutions, could be stopped by the police and sent to the hotspot in Taranto if they did not present the appropriate documentation. In France, the situation was not very different. In cities as distant from the border as Nice, or even in Marseille, the police could require documentation at train and bus stations from persons considered to be in transit from Italy, and deport them back if they did not meet the administrative requirements (on the process of determining the 'suspects' of being in an irregular situation see Aris Escarcena 2018). Deportation became thus a 'sword of Damocles' for migrants in transit between Italy and France.

\section{The (lack of) response from Catholic organizations}

The Catholic organizations providing shelter and food assistance in Ventimiglia did not actively oppose deportation policies. Their limited engagement with these issues concerned mainly deportations of unaccompanied minors; actions that depended on professionalized sectors, completely detached from the local voluntary sphere of these organizations. The absence of direct intervention on the part of the Catholic organizations requires a reflection on the limitations of Catholic activism. 
However, it is important to point out that apprehensions enforced for the purposes of deportation within the Italian territory did not occur in the places where Catholic organizations operated, thus, leaving some 'safe' places for migrants in Ventimiglia. The 'protected areas' were in evidence near the Delle Gianchette Church. Except for the informal camps located under the bridge and on the banks of the river, the street leading to the church saw many apprehensions, but the police never stopped the young migrants who occupied the public benches located in the square at the entrance of the church. In the same street, there was a center set up by the 'Eufemia' organization. It became known as the 'Infopoint,' where multiple services were offered to migrants, including an ability to charge telephones, gain access to the Internet or receive legal aid. Numerous migrants came to the 'Infopoint.' However, unlike in the previous scenario, they were frequently detained.

The relationship between the humanitarian structures of the Catholic Church and the social policies of the State is one of the major obstacles to the political positioning of local Catholic activism. At the local level, this is expressed, on one hand, in the immunity of Catholic organizations and their volunteers from policies of repression that affected other organizations, and on the other hand, in the acceptance of migration management decisions and policies that went beyond the humanitarian threshold. This limitation of Catholic organizations to the exclusive implementation of humanitarian/caritative projects is the main drawback of the leadership of Catholic organizations. There are two explanatory dimensions to this issue: 1) Catholic social and humanitarian assistance organizations have become bureaucratized. As T. Waters (2018) explains, this bureaucratization entails serious limitations and results in professionalization, technification, and depoliticization of humanitarian assistance; 2) charity, as a cultural value, has a limitation since it presents assistance as a disinterested concession and does not question the origins of the need for assistance. If humanitarian assistance is exercised as a depoliticized action, charity acquires a paternalistic connotation.

\section{Catholic leadership, between 'euergesia' and social justice}

The leadership of Catholic charity organizations established a final line of defense in situations of complete vulnerability of migrants. The ability to respond to the distress of migrants is a final safeguard when the policies of authorities (local or national) challenge deeply rooted social values. Its potential has been demonstrated by mobilizing social sectors that would otherwise hardly have been involved in activities in support of migrants. This cultural and social capital has been based on the need to defend the social values that are being put at risk. The erosion of rights and the loss of the capacity to exercise basic rights must be considered in relation to the erosion and impoverishment of the cultural systems, in which they are sustained. Resistance to this situation of violation is based on the defense of shared values, which is one of the most basic forms of identification and social belonging. 
However, the issue remains the same as formulated by Muehlebach (2013: 462): 'how we differentiate between paternalistic charity and justice, and how we make charity morph into radical solidarity.' While the leadership of Catholic organizations is an enormous boost in the creation of a last line of defense for migrants, the dynamics of their activism strengthen a limited interpretation of social values, an interpretation that has not allowed us to imagine new forms of social articulation around them. In the analysis of the reconfiguration of values today, it seems useful to reintroduce the concept of 'euergetism' in the sense used by A. Boulanger and his followers, especially B. Dumézil (2005). Here the value of charity is understood as a paternalistic activity exercised as a moral gesture offered from a position of superiority. In this sense, it is opposed to charity understood as a basis for justice. 'Euergesia' would be a social behavior motivated by the same moral principle but opposed in its development into (social) justice. From this point of view, there are two fundamental factors that determine the preponderance of the euergetic sense in the development of humanitarian assistance: 1) the victimization and inferiorization of the subject of assistance, 2) the dislocation between the benefactor and the assisted, and the potential inversion of the sense of the distributive relationship. The depoliticization of projects to assist migrants can lead to the emergence of both factors and, therefore, condition the way in which the assistance action is understood.

Marcel Mauss points out in the 'Moral Conclusions' of 'The Gift' (1966: 63) the need to think of social assistance not as charity but as a social debt contracted as a group with the people who are part of it; and in another fragment (pp. 15-16) he shows the original semantic union of the word charity with justice. There exists today the political need to imagine how to connect the great social agreement existing around the principle of humanity that upholds values such as charity (understood as justice and not as paternalism) with political inclusion projects in the sense presented almost a century ago by Mauss.

\section{Conclusions}

The mobilization of civil society by Catholic organizations has been a positive experience in Ventimiglia. The activities of the Catholic organizations defended migrants' rights from the most aggressive policies that left them destitute. This ability to generate a final line of defense for migrants in the face of the violations of their most basic rights has been based on a call for mobilization around socially rooted values such as charity.

The experience of the Delle Gianchette Church in welcoming migrants and defending their dignity is a seminal example of how Catholic organizations can mobilize great cultural and social capital among local populations. The projects of the Delle Gianchette Church and Caritas Ventimiglia-San Remo can be seen as expressions of local societies' commitment to defend migrants' basic rights (to housing, to not fear persecution or violence, to 
dignity). The ability to appeal to the fundamental values of civil society (values with which the society identifies culturally) has served to oppose the more violent effects of policies that sought to create an unsustainable situation for migrants in Ventimiglia.

The 'immunity' to prosecution and police control (as well as police harassment) granted to volunteers by the leadership of Catholic organizations is an important element in understanding the legitimacy of volunteers as agents who channel and express the convictions of the population before the authorities. In a context marked by the repression of volunteerism, no Caritas volunteer or participant in the Delle Gianchette Church reception project has been prosecuted, arrested, expelled, or removed from the territory of Ventimiglia, as was the case of volunteers who carried out the same type of activities under the coordination of other types of organizations such as No Borders (e.g. expelled under the foglio di via).

In addition to the potentialities of the Catholic organizations' leadership in the social mobilization for the defense of migrants, its limitations and risks have been analyzed. The main limit of this leadership is the inability or lack of will to include a critical positioning in the political sense. The defense of migrants' rights has been led only in areas where it could be exercised with direct assistance to immediate needs and without confronting government authorities. These organizations did not question the policies that kept migrants in a situation of vulnerability, but rather faced their effects. In the case of Ventimiglia as a border area, this has materialized in the fact that Catholic organizations have not participated in defending migrants' right to free movement, remaining on the sidelines of criticism of deportation programs both between the States of France and Italy and within Italian territory.

This limitation questions the interpretation of the value of charity from the perspective of Catholic organizations' activism. If its main potential is the capacity to generate broad-based social support for the defense of the basic rights of migrants, its depoliticization of such defense may imply paternalistic bias in the understanding of these values and the loss of the possibility of a deeper demand for social justice as an inclusive project.

\section{Notes}

1 Since the French and Italian governments exert (physical and symbolic) violence on migrants in the border area, the presence and activity of these organizations serves not only as support, but also as a real defense for migrants.

2 Theoretically, charity has been defined in different ways by the Catholic Church. Fundamental to Christian doctrine are the encyclical letters 1) 'Rerum Novarum' by Leo XIII (1891) and 2) the 'Sollicitudo Rei Socialis' by John Paul II (1987), where the relationship between solidarity and charity - an important issue for this analysis - is established (para. 40).

3 This research is the basis of the documentary project 'Solidarity Crime. The borders of democracy' www.solidaritycrimemovie.com. 


\section{References}

Alldred, P. (2003). 'No borders, no nations, no deportations,' Feminist Review 73(1), pp. $152-157$.

Aris Escarcena, J. P. (2018). 'La paradoja del taxista: Ventimiglia como frontera selectiva,' Mondi Migranti (2), pp. 99-114.

Aris Escarcena, J. P. \& Da Silva, A. C. (2018). 'Deterring solidarity on border spaces: A comparative analysis of food distribution bans in Ventimiglia and Calais,' in Altamirano, D. R., Totah, F. M., \& Keles, F. (eds) Porous Borders, Invisible Boundaries? Ethnographic Perspectives on the Vicissitudes of Contemporary Migration. Washington DC: CORI/SUNTA/AAA.

ASGI (2018). Se questa è Europa - Minori stranieri respinti dalla Francia all'Italia. Asgi.

ASAFFRON Association (2017). 'Grounded theory and ethnography in the study of transit-mobilities of refugees in border zones. Challenges from fieldworks (Italy/ Greece) with people fleeing Syria,' Revista Internacional de Estudios Migratorios 7(3), pp. 131-152.

Burridge, A. (2010). 'Youth on the line and the No Borders movement,' Children's Geographies 8(4), pp. 401-411.

Dumézil, B. (2005). Les Racines Chrétiennes de l'Europe: Conversion et Liberté dans les Royaumes Barbares, Ve-VIIle siècle. Paris: Fayard.

European Union (2000). Council Regulation (EC) No 2725/2000 of 11 December 2000 concerning the establishment of 'Eurodac' for the comparison of fingerprints for the effective application of the Dublin Convention.

European Union (2013). Regulation (EU) No 603/2013 of the European Parliament and of the Council of 26 June 2013 on the establishment of 'Eurodac' for the comparison of fingerprints for the effective application of Regulation (EU) No 604/2013.

European Union (2016). Regulation (EU) 2016/399 of the European Parliament and of the Council of 9 March 2016 on a Union Code on the rules governing the movement of persons across borders (Schengen Borders Code).

Faiola, A. \& Birnbaum, M. (2015). 'Pope calls on Europe's Catholics to take in refugees,' The Washington Post, 6 September. Available at: www.washingtonpost. $\mathrm{com} /$ world/refugees-keep-streaming-into-europe-as-crisis-continues-unabated/2015/ 09/06/8a330572-5345-11e5-b225-90edbd49f362_story.html?noredirect=on\&utm_ term $=.2 \mathrm{ff5} 5 \mathrm{~b} 7665 \mathrm{~d} 86$

Giliberti, L. (2018). 'La criminalizzazione della solidarietà ai migranti in Val Roja: Note dal campo,' Mondi Migranti (3), pp. 161-181.

Gray, B. (2016). 'The politics of migration, church, and state: A case study of the Catholic Church in Ireland,' International Migration Review 50(2), pp. 315-351.

Hess, S. \& Kasparek, B. (2017). 'De- and re-stabilising Schengen. The European border regime after the summer of migration,' Cuadernos Europeos de Deusto 56, pp. 47-78.

Mauss, M. (1966). The Gift. Forms and Functions of Exchange in Archaic Societies. London: Cohen \& West.

Muehlebach, A. (2013). 'The catholicization of neoliberalism: On love and welfare in Lombardy, Italy,' American Anthropologist 115(3), pp. 452-465.

Noborder Network (2004). About noborder.org. Available at: www.noborder.org/about. php.html

Pardun, J. T. (1997). 'Good Samaritan laws: A global perspective,' Loyola of Los Angeles International and Comparative Law Journal 20. 
268 J. P. Aris Escarcena

Quadroni, A. \& Luppi, M. (2016). 'Il “giro dell'oca” dei trasferimenti coatti,' Open Migration.

République Française, \& Repubblica Italiana (2000). Décret $n^{\circ} 2000-652$ du 4 juillet 2000 portant publication de l'accord entre le Gouvernement de la République française et le Gouvernement de la République italienne relatif à la réadmission des personnes en situation (ensemble une annexe), signé à Chambéry.

Tazzioli, M. \& Walters, W. (2019). 'Migration, solidarity and the limits of Europe,' Global Discourses 9(1), pp. 175-190.

Volunteer 1 (2017). Interviewed by J. P. Aris Escarcena at Ventimiglia, December 16.

Waters, T. (2018). Bureaucratizing the Good Samaritan. New York: Routledge. 